\title{
ISLAM IN SOUTHEAST ASIA: REFLECTIONS AND NEW DIRECTIONS
}

Anthony H. Johns

\begin{abstract}
"The Study of Islam in Southeast Asia" is an expression with a compelling ring. It suggests a well defined field of research, a tradition of scholarship, adequate points of orientation, and an authoritative structure of monographs, articles in learned journals, and more general works. The reality however is more complex and at the same time more limited than the expression "Southeast Asia" suggests. In practice it has generally meant a study of Islam in those areas which 1ie within the ambit of the new nation states of Indonesia and The Federation of Malaysia, although there are significant Muslim communities in Thailand, Burma and among the Chams in Cambodia. It is, however, only in Malaysia and Indonesia that Islam exists in any strength and is shared by a wide range of ethnic groups and social classes. And despite the very substantial volume of painstaking and important scholarly writing devoted to the subject, it is still not possible to present a definitive picture of the role of Islam in the past and present of the region.
\end{abstract}

There are various reasons why this is so. The most important are severe fragmentation of the Southeast Asian region; the absence of any central, stable core of Islamic civilization and learning in the region to which the further development of Islam can be referred, and the paucity of indigenous written records until the beginning of the seventeenth century. Nevertheless two general works have appeared: Is lam Comes of MaZaysia, by S. Q. Fatimi, and Is Zam Observed by Clifford Geertz.l Both are written with sweep and imagination. The subtitle of Geertz's book is Religious Development in Morocco and Indonesia. In fact the Indonesian component of the book is limited to Central Java, and Geertz writes with a poetic sensitivity to a particular Javanese view of Islam and of Islamization. Yet this Javanese view is no older than the eighteenth century and derives from the role and character accorded to Islam by the court culture of Central Java of this period. It has no relevance to the character of Islam as it was first preached in the Malay archipelago three or four centuries earlier, nor to Islamic belief and practice as it developed in other regions of the island world.

Fatimi's book is concerned not so much with the specific spiritual character of Islam, but with the sources from which it came. He makes use of a wide range of Arabic and Persian sources and refers to certain Malay works. On this basis he develops two major hypotheses: that the principal source of Malaysian Islam was Bengal, and that Islam first appeared in "Malaysia" from the east in the course of the eleventh

1. S. Q. Fatimi, Islam Comes to Malaysia (Singapore: Malaysian Sociological Research Institute Ltd., 1963); C. Geertz, Islam Observed (New Haven \& London: Yale University Press, 1968). 
century via a Canton, Phan'rang, Trengganu and Lèran (East Java) axis. ${ }^{2}$ Despite the fluency and verve of his exposition of these ideas, the reader is nonetheless left with a certain disquiet as to the validity of the arguments, and perhaps with more interest in arguing the strengths and weaknesses of the hypotheses than in seeking to discover the specific articulations of Islam in the status systems, structure of government, ideological concerns and international relations of those areas in which it became established.

In 1968 Drewes published a long and useful article, "New Light on the Coming of Is lam to Indonesia?" (the question mark is an integral part of the title). ${ }^{3}$ In it he treats critically Fatimi's hypotheses in the framework of a general survey of the theories put forward by European scholar's concerning the place of origin of Islam in the East Indian Archipelago, from Crawford in 1820 who mentioned Arabs, but also referred to "intercourse with the Mahomedans of the Eastern coast of India," to Keyzer who proposed Egypt (1859), to Niemann (1861), de Hollander (1861), and Veth (1878), who spoke only of Arabs. New ground was broken by Pijnappel in 1872, who saw Islam brought to the Indies by Shăficite Arabs of the Gujerat and Malabar. This approach was developed by Snouck Hurgronje (1883), who saw the merchants of the port cities of the Deccan as the bearers of Islam to new territories. ${ }^{4}$ It was refined by Marrison in 1951, who attempted to specify the region of South India from which Muslim traders set out, and gave special attention to the Coromandel Coast. ${ }^{5}$ For Drewes then, it is a study of Islam in South India that can offer a better understanding of the coming of Islam to the Indies, and he concludes his article: "Resumption of the archaeological research in North Sumatra and painstaking study of Islam in South India--for which a thorough knowledge of Tamil is indispensable--appear to be primary requirements."6

It will be noted that although much has been written on the provenance of Southeast Asian Islam, comparatively little has been written on the modality of its spread and even less on the social and political effects of the new religion, and the subsequent character of the centers of political power where it developed. This is a difficult question because materials are so fragmentary. Such as they are, they are out of the reach of scholars concerned with the West Asian heartlands of Islam, who rarely, if ever, refer to Southeast Asia. For the scho1ar of both wings of the Muslim world then, a sense of perspective is missing: for in the sixteenth and seventeenth century constellation of global politics, Istanbul and Aceh were equally parts of the Muslim world.

As if these difficulties were not enough, they have been compounded by the "generalists" and social scientists of the twentieth century who only know the region as consisting of Indonesia and Malaysia, and address themselves to describing and "explaining" Indonesia and Malaysia without taking sufficiently into account the modalities of the existence of these states or their parvenu character. There is a tremendous pressure, for example, to use the term "Indonesia" ana-

2. S. Q. Fatimi, Islam. For the Bengali origin of Malaysian Islam, see chapter III, especially pp. 13-21. For the line of eastern penetration, see chapter IV, especially pp. 37-49.

3. G. W. J. Drewes, "New Light on the Coming of Islam at Indonesia?" Bijdragen tot de Taal-, Land-en Volkenkunde (BKI), CXXIV, No. 4 (1968), pp. 433-59.
4. Ibid., pp. 439-41.
5. Ibid., pp. 444-45.
6. Ibid., p. 459 . 
chronistically. And even a scholar as meticulous as Drewes writes of "Indonesia.. . her conversion to Islam set in when this religion had already achieved its definitive form. . . . Indonesia has shown great receptivity and an amazing faculty for adapting newly acquired ideas to her old basic pattern of thinking, but she has not displayed any creative impulse."7

Even given the nature of a general paper in which these remarks are presented, it cannot be insisted too strongly that the personification of Indonesia in this way is misleading. What is now Indonesia and its neighbors include many peoples of different backgrounds, patterns of livelihood, and languages, not all of whom have been Islamicized in the same way and to the same degree. The only sense in which one can speak of Indonesian Islam is when one is describing the normative centralizing role of the Ministry of Religion. No further general statement is possible until some perception has been gained of the varieties and discontinuities in the history of Islam in the region before the birth of Indonesia. The abuse of the term "Indonesian" then effectively masks the complex processes of the past, both because it leads to a confusion with Indonesia as a political entity, and suggests the stable existence of a particular center of authority, and a homogeneous continuing cultural identity.

It is unfortunately true that the term "Islam" has also been used with as little precision. This is in part because, as C. J. Adams points out, many social scientists, economists, sociologists and political scientists have done field work in the developing countries, some of which have been Muslim. They have to this extent been involved in Islamic Studies of a kind, but only to the extent that Islam has some bearing on their central disciplinary concern. ${ }^{8}$ But in part it is also because Islam itself is a polyvalent term, and to study its role in a community with any attempt at understanding its significance, it is necessary to have some idea of its functions.

For the Westerner, if the specific character of Islamic experience is to have any meaning for him at all, it must be seen as a technique of individual salvation which answers the question: what must I do to be saved? But it is at the same time a regulator of family relationships and the organizing principle of a state. From these aspects, it represents a system of 1 aw. It is further a tool of ontological analysis, a means of understanding the nature of existence, the meaning of the creation of the world, the character of the Creator, generating discussion as to the necessity or otherwise for human existence at all, and thus begetting systems of theology, philosophy and mysticism. In a more general sense it is used to characterize forms of artistic expression which are sufficiently identified if they are called Islamic. And yet more generally still, it is used simply as an expression of community identity.

Not all of these functions need exist together. A man may live as a Muslim, as an individual, in a part of the world in which he has no co-religionists. A family, nuclear or extended may live according to

7. G. W. J. Drewes, "Indonesia: Mysticism and Activism," in Gustave E. von Grunebaum (ed.), Unity and Variety in Muslim Civilisation (Chicago: University of Chicago Press, 1955), p. 284.

8. C. J. Adams, in "The History of Religions and the Study of Islam," a paper read at the meeting of the American Academy of Religion in Chicago in 1973. It was reprinted in ACLS Newsletter, XXV, Nos. 3, 4 (Summer-Fall 1974), pp. 1-10. 
Muslim Law either with or without the umbrella of a Muslim State either to shield its members, or to apply sanctions for transgressions of that law. The number of individual Muslims who become legists, philosophers or mystics is few. But although specialized religious learning is not a requirement for every Muslim, it is a requirement for the cohesion of the Muslim community and for the furthering of the tradition of Islamic education. The physical hallmarks of Islamic civilization may remain where a Muslim community no longer exists; a community with tenuous links with Islam may identify itself as Muslim to distinguish itself from other communities which it dislikes.

It is possible to extend this analysis. But it should be clear from these examples that the blanket use of the word "IsIam" conceals the fact that one is not coming to terms with an abstraction, but with people; that the term is complex: it cannot meaningfully be discussed as a tide, but rather as a web of dynamisms and tensions. Accordingly, any simplistic assertions about Islam being this or being that, doing this or doing that, coming from here or coming from there are fraught with horrendous limitations.

All of these functions of Islam are to be discovered in Southeast Asia, and their distribution testifies the great variety in the manifestations of Islam to be found there. This distribution and variety is not a constant. It has been shifting and changing with the political and cultural history of the Indies since the first sultanates were established at the end of the thirteenth century, in a region of a variety of peoples, social structures, means of livelihood, cultures and religions. Denys Lombard puts it well, when summarizing the range of ideologies in the region he says:

We are in fact dealing with several levels of mentality, and that in such cases the diachronic dimension is particularly necessary. The thought-processes of fringe societies in which "potlatch" is a prevailing custom (the Toraja); those of concentric agrarian societies (the Indo-Javanese states and their off-shoots at Jogja and Surakarta); those of trading societies (Malay towns, pasisir); those of the societies living in large modern towns, and above all, the interplay of these various processes on each other, and their inter-relationships. ${ }^{9}$

The types of society in the Indies that have to some extent or other been Islamicized are not less complex. It is therefore important to be clearly aware of what conceptual tools and disciplinary competences are going to be valid for any particular place and time. What the anthropologist is able to observe in surveying a village, or the types of analysis that he can produce will give a different picture than those of the economist who makes a survey of the business life of an entrepreneurial community, or the political scientist who attempts to understand the character of Islam as understood by the central government of a modern state, or a particular aspect of Islam articulated by a pressure group with particular social attitudes, or the power structure and attitudes of a particular court. Although the investigator into all these areas needs a particular knowledge of Islam, yet the discipline he needs to practice in each case is different.

9. Denys Lombard, Scientific Information Document, prepared for UNESCO International Meeting of Experts for the launching of the Malay Culture Project, January 21-28, 1972. p. 19. 
At the same time it must be stressed that Islamology, too, is a discipline in its own right, distinct from anthropology, sociology or economics, even though these disciplines may contribute to it. Gaining an intellectual and sympathetic mastery of a religion is in some respects analogous to learning a language, for a religious tradition carries with it a view of the world in much the same way as a language; yet just as the knowledge of a language does not give a scholar an automatic mastery of particular disciplines, so the knowledge of a religion, while it may illuminate the workings of a society, cannot replace the study of a society through the social sciences. Moreover, the student of a religion may make errors analogous to those of a student of a foreign language in misreading the value systems of the religion, or, as the foreign speaker of a language is influenced by his own speech habits, so the foreign student of a religion may impose upon it a wrong distribution of emphases and values.

All these demands create a well nigh impossible task for the historian of Islam, who in effect is forced to fight indecisive round after indecisive round against an elusive enemy. For my purposes, the bell signaling the start of this round is Goitein's description of the intermediate period of Islamic history, which he places between 850 and 1258 A.D. He calls it "intermediate" because he sees it as "intermediate in time between Hellenism and Renaissance, intermediate in character between the largely secular culture of the later Roman period and the thoroughly clerical world of Medieval Europe, and intermediate in space between Europe and Africa on the ond hand, and lndia and China on the other hand, thus forming, for the first time in history, a strong cultural link between all parts of the ancient world. . characterized by the predominance of the middle-class, which thrived on a free enterprise economy. . . "lo These social and economic features of Islamic society were not wiped out by capture of Baghdad by the Mongols. In a special sense they were part of the genius of Islam, which provided the framework for the intellectual and economic blossoming of a middle class that was not to find a parallel in Western Europe until the Protestant Reformation five centuries later. Thus they remained an important element in the new territories to be incorporated into the domain of Islam in South and Southeast Asia.

Another aspect of this "intermediate civilization" implicit in Goitein's statement is set out in Hourani's The Islamic City, in which he shows quite clearly the importance of a bourgeois-"ulama" nexus in the social structure of the Islamic City, the mutual interdependence of mercantile activity and the maintenance of Islamic educational institutions.l In other words the history of Islam in Southeast Asia cannot be understood apart from the history of the generation of trading centers at focal points in the archipelago.

The urban history of our region is freakish, disparate and abrupt. The process and character of Islamization is therefore of the same character. The concern of scholars for the source of Islam in this part of the world has obscured this fact. Lines of communication be tween urban centers in the archipelago cannot be taken for granted, so nothing is gained and much may be lost by assuming any consistency or

10. S. D. Goitein, Studies in Islamic History and Institutions (Leiden: E. J. Brill, 1966), pp. 59-60 and 55.

11. A. H. Hourani and S. M. Stern (eds.), The Islamic City (Oxford: Bruno Cassirer and the University of Pennsylvania Press, 1970), pp. 21-22. 
identity between the development of religious schools and centers of learning in Malacca, Aceh, Palembang, Banten, the port cities of Northeast Java or Makassar. Each was autonomous, each was open to the influence of a particular school of religious teachers, and rivalries could result in bitterness, persecution and book burning.

This however is to anticipate. If the development of Islam in Southeast Asia cannot be understood apart from the history of trading centers generated at focal points in the archipelago, this process in its turn cannot be isolated from the maritime history of the Indian Ocean and the South China Sea. The character of this trading system at the end of the fifteenth century is graphically expressed by Hale, who remarks that once Bartolomeu Dias and his fleet had rounded the Cape of Good Hope in 1498, and made contact with Mozambique ". . . they entered a highly sophisticated trading area with maps, pilots using quadrant and compass, and a busy traffic of large ships. The Indian Ocean resembled an Arabic-speaking Mediterranean, and with interpreters from the Iberian peninsula or North Africa, Europeans could master its intricacies without too much difficulty though not, of course, without facing much danger and inevitable hardship."12

This concept of an Arabic speaking Mediterranean and its implications for the study of the past of the region should be taken seriously. Schrieke notes that ". . . the squadron of ships from Zealand which called at Achin on 23 August, 1601, after having visited the island of Anjouan, one of the Comoro Islands off the east coast of Africa, the previous month, had been given a letter of recommendation in Arabic to carry from the island to the Sultan of Achin."13

He also adds that ". . . the ruler of Acheh's letters of introduction were written in Arabic and that James Lancaster--carried on his negotiations in 1602 in the same tongue. . . . the same was true of Patani."l4 It appears that even the English had managed to master the intricacies of Arabic for the purposes of trade in this "Arabic-speaking Mediterranean."

The involvement of sailors and ships from the Indies in this system is very ancient. Without going back as far as the days of Sri Vijaya one may simply cite Schrieke's reference to the role of Malays as sailors as far afield as East Africa in materials drawn from various sources. He refers to Idrisi writing in 1154 that Malay ships, or at least ships from the Zābag Islands regularly fetched iron from the Sofäla Coast of eastern Africa; he notes that in 1346, Ibn Battuta returning from Chuanchow went to Sumatra in a junk manned by Malays; Ibn Battuta, according to Schrieke, also mentions Malays among the traders who frequented $\mathrm{Calicut}$ on the Malabar Coast, and Malays along the coast of Benga1. In 1440, Schrieke observes, "Abd a1-Razzăq met with Malays even at Hormuz."15

It is from participation in this trading system that the beginnings of Islam in the Malay world derive; and for this first stage of Islamization the question of a specific point of origin for any particular

12. J. R. Hale, "Renaissance Europe: 1480-1520," in Carlo M. Cipolla (ed.), Fontana Economic History of Europe (London: Collins/Fontana, 1972-73), pp. 50-51.

13. B. J. 0. Schrieke, Indonesian Sociological Studies (The Hague: Van Hoeve, 1957), II, p. 245 .

14. Ibid., p. 388, n. 96 . 15. Ibid., pp. 244-45. 
Muslim community is not of primary concern. One can, and need go no further than to say that there was a kind of Islamic "fall out" around the shores of the Indian Ocean; that as the Muslim character of the mercantile history of the Indian Ocean and of the silk road through central Asia became more pronounced, new Muslim trading communities were generated at the focal points of international trade and local barter. It is irrelevant whether the nascent Muslim communities were generated by contacts with Bengalis, Chinese, Tamils, Gujeratis, Persians or Yemeni Arabs, whether in succession or in varying proportions, the elements of which did not remain constant over the years. In fact there is no single answer as to the question of the whence of Islam in the Malay world. The concept of the Indian Ocean as an "Arabic-speaking Mediterranean" has, as a corollary, a variety of ethnic cultures participating in the system: Tamil vessels, Chinese vessels, Persian vessels, Arab vessels with a wide variety of crews, travelers and religious teachers.

The first Islamic port cities in the region, beginning with the Sultanate of Pasai in the thirteenth century were the consequences of this "fall out." If Pasai was the first, it was in the next two centuries followed by others, at other points on Sumatra, on the Malay Peninsula, the north coast of Java, Borneo and the Celebes. Increasingly, settlements at the focal points of our region were drawn into the affairs of the "Arabic-speaking Mediterranean," and generated Muslim city-states which either developed to fill a power vacuum, where no rival state existed, as in the case of Malacca, or challenged and took over already existing maritime states.

It was this generation of Muslim city-states that was gradually to diffuse waves of Islamic influence into the hinterland, and which was to lead to the Islamization of broad swathes of the indigenous population. The modality of this Islamization is unknown. One view is that the process began when Muslim merchants stopped off at particular settiements, perhaps between one monsoon and the next, perhaps for longer periods, and married the daughters of local chiefs. It must be stressed that there is an expansive dynamism inherent in Islam in even the smal1est Muslim community, which by its very nature is jealous of its independence. It has the nucleus of the organization of a state: it has the principles of social order and community government--it has the flexibility to adapt itself to any environment, and cannot accept the legitimacy of any other power exercising authority over it. There is a progression then from a group, to a self-governing community, to a politically active community which becomes strong enough to seize power and establish its own authority. One might see in the process, a repetition in microcosm of the first community of Muslims in Mecca gathered around Muhammad.

It is not possible to document these stages in the history of Islam in the Malay world. Yet at some moment of incandescence a Muslim city-state emerges which enters into relations with other Muslim states in its own right, its rulers greet each other with the Muslim greeting of salām, its members make the pilgrimage, study in the holy land, and return home with the learning status and authority that such a sojourn has gained them, and more important, develop a self-sustaining educational system.

It is such educational institutions which are crucial to the Islamic character of any Muslim city-state, and the further local diffusion of Islam. It is from such institutions, little indeed as we know of them, that derive a large proportion of the manuscripts (MSS) relat- 
ing to Islam learning from our region, beginning with the very small number taken home by the first voyages of the Dutch and British trading companies from the end of the sixteenth century onwards. It is from local studies of states and institutions of this kind that any genuine history must begin, for they are the lynch pins of Islamization in the region.

Such a point of departure is easily formulated. Further journey along the road is more difficult. At one time it seemed that the Hikayat Raja-Raja Pasai (Chronicie of the Kings of Pasai) 16 gave an account of this, the first Muslim state of the archipelago, and served as a model for the court chronicle of the later state of Malacca (14001511). The status of this text has always been somewhat anomalous, and since Teeuw's essay (1964) ${ }^{17}$ suggesting that it is a work subsequent to the Malaccan Annals (The Sejarah Melayu), 18 but drawing on the same traditions as the sejarah Melayu, it cannot be regarded as a very authoritative guide to events in Pasai during the thirteenth and fourteenth centuries.

This means that the starting point must be the Sejarah Melayu itself. The Sejarah Melayu enjoys a high reputation. Winstedt refers to it as the most famous, distinctive and best of all Malay literary works, and refers to the author's familiarity with Muslim stories such as the Romance of Alexander the Great and of Muhammad Hanafiyya, and to his being versed in the esoteric knowledge of the Sufi mystics of Pasai and Malacca.19 Unfortunately the Sejarah Melayu does not provide the bedrock one would have hoped. It is known in two main rescensions, represented in most discussions by the Raffles Ms and the Shellabear edition. 20 It was generally believed that the Raffles 18 text derived from a version written before 1536, and the Shellabear edition from a version prepared in 1612. Roolvink 21 has argued convincingly that the Raffles text in fact derives from a 1612 version, and the shellabear edition from the second half of the eighteenth century. This raises numerous issues, including, for example, whether the Hikayat Raja-Raja Pasai was compiled before or after the 1612 version. This aside however, a comparison of the Raffles and Shellabear versions of the text show that it was a continually evolving work to which episodes were added, and in which they were rearranged and emphases changed over the passing of the years.

Islamic:

Be this as it may, there are six principal references to things

16. A. H. Hill (ed. and trans.), "Hikayat Raja-Raja Pasai," Journal of the Malaysian Branch of the Royal Asiatic Society (JMBRAS); XXXIII, No. 2 (1960).

17. "Hikayat Raja-Raja Pasai and Sejarah Melayu" in John Bastin and R. Roolvink (eds.), Malayan and Indonesian Studies (Oxford: Clarendon Press, 1964), pp. 22234 .

18. The Raffles $18 \mathrm{Ms}$. edited by R. 0 . Winstedt was published in JMBRAS, XVI, No. 3 (1938). References are to the translation of this text by C. C. Brown in JMBRAS, XXV, Nos. 2 and 3 (1952), entitled "Sejarah Melayu" or "Malay Annals."

19. Sir Richard Winstedt, "A History of Classical Malay Literature," JMBRAS, XXXI, No. 3 (June 1958), pp. 129-31.

20. The Shellabear text has been republished as Sejarah Melayu (Kuala Lumpur: Oxford University Press, 1967).

21. R. Roolvink, "The Variant Versions of the Malay Annals," BKI, CXXIII, No. 3 (1967), p. 311. 
1. The introductory chapter which relates the invasion of India by Iskandar dhu' 1 -Karnayn, and his induction of Raja Kida (sic) Hindi into the religion of Abraham (that is, a religious dispensation preceding that of the prophet Muhammad).22

2. The conversion of the ruler of Malacca to Islam in chapter VI. The text tells how the third ruler of Malacca has a dream in which the prophet Muhammad appears to him in a dream, teaches him the confession of faith, and tells him that a ship will arrive from Jeddah the following afternoon carrying a man who will teach him the true religion. The ship arrives, the holy man disembarks and receives Raja Tengah--henceforth to be known as Sultan Muhammad Shah--and all his chiefs into Islam.23

3. The arrival of Mawlana Abu Baku (from Mecca) with a book Durr Manzum, which is sent to Pasai either for explanation or authentication, and received back in Malacca. 24

4. The story of a theological problem submitted to Pasai by Sultan Mansur Shah, who sends an envoy, Tun Bija Wangsa, to ask whether those in heaven and hel1 remain there forever. The envoy takes with him seven tahils of gold dust and two concubines to be presented to the Pasai theologian who can answer the question. The first answer given is based on the Qur'an: they remain there forever. But one of the Pasai theologians has second thoughts, realizing that the ruler of Malacca would not have sent so far afield for so obvious an answer. Thus an esoteric answer (not stated) is given in private to the Malaccan envoy to the latter's satisfaction, and the gold and concubines change hands. 25

5. Malacca refers to Pasai a question in dispute in Transoxania, Iraq and Khurassan. The question concerns the reconciliation of the two statements: "One who says that God is creating and sustaining in pre-eternity (azal) is an unbeliever"; and "One who says that God is not creating and sustaining in pre-eternity (azal) is an unbeliever." The question is taken, and the answer given to the satisfaction of the Malacca court. The text does not divulge the answer. 26

6. In Chapter XXIII, there is an episode describing the request of the commanders of the Malacca army the night before the Portuguese assault on the city, to read the story of Muhammad Hanafiah (one of the Prophet's companions); in reply, the Sultan is as first disposed only to allow them to read the story of Amir Hamzah, an "uncle" of the Prophet, and of lesser rank than one of his companions. 27

There are other references to Islam and to Islamic teachers and Kadis, but these are the most important. So far from showing that the annalist was "versed in the esoteric knowledge of the Sufi mystics of Pasai and Malacca" they suggest that he knew only a few Arabic tags and phrases. All the references to Islam are superficial in character whether the fragments quoted from the Alexander Romance, the stereo-

22. Brown, "Annals," Bk. I, pp. 12-16.

24. Ibid., Bk. XII, p. 100.

26. Ibid., Bk. XX, pp. 154-55.
23. Ibid., Bk. VI, pp. 52-54.

25. Ibid., Bk. XX, pp. 100-102.

27. Ibid., Bk. XXIII, p. 168. 
typed picture of the conversion of Raja Tengah to Islam (the announcement in a dream of the coming of a holy man to preach the religion, and his arrival at the time and at the place foretold); the rather lighthearted treatment of the "answer of Pasai" which suggests that the chronicler was more interested in how the gold and concubines were to be won by the correct answer to a riddle (a motif almost as old as time) than in theology; and the question discussed in Iraq, Khurassan and Transoxania falls into the same riddle category. In this, these Islamic colored episodes share the same general ad hoc character of the Sejarah Melayu as a whole, which is studded with anecdotes, some of which are entertaining. But virtually all are simply reworked motifs from various sources inserted into the narrative without regard for any functional role by which they might serve to integrate character and moral judgment. In effect then, we are not much better off for an understanding of the role of Islam in fifteenth century Malacca than we are for fourteenth century Pasai.

We are also not much better off for the coastal cities of fifteenth century.Java. The seventeenth century Babad Tanah Jawi28 gives fairly full accounts of the saints of Java to whom are attributed the preaching of Islam on the island. Yet although graves are honored as the last resting place of some of them, they remain shadowy figures, no more convincing than the eccentric or cowardly teachers of religion to be found in the sejarah Melayu. Whatever their historical reality may have been, in the Babad Tanah Jawi they are mythologized into figures of more concern to the dynastic history of Java than the establishment of a tradition of Muslim intellectual 1 ife on the island.

It is important to reiterate what intellectual life in Islamic civilization means. It includes fields of study as diverse as Law, Grammar, Scholastic Theology and Mysticism. And this intellectual life itself is not a single tradition, but a complex web, reflecting differences in schools, points of departure, rearrangements of emphases all of which served to create rivalries, hatreds and a competition for royal patronage. The strands in this web are so complex, and the evidence necessary to isolate them so fragmentary, that it is difficult enough to discover their beginnings and their ends, let alone untangle them. What this means--and it is only at this point that the term "history" has any real meaning--is that it is necessary to discover to what intellectual and spiritual traditions that the individual courtkingdoms belonged; or to put the matter more precisely: to set any individual teacher of Islam in the Malay world at a point in the network of teachers sustained by schools of learning and the organizational networks of the Sufi orders, and thus learn in detail--at first hand-something of the intellectual world of Medina, and other centers of learning in the Middle East in which they participated. It is only information of this kind that can make it possible to put into order many of the MSS fragments of Muslim works of various kinds from the Malay world scattered in the libraries of Europe, Indonesia and Malaysia.

An important date is 1526 , which marked the establishment of the sultanate of Banten, a port city on the north coast of Java, a few miles to the west of what is now Jakarta. This was the port into which the first Dutch trading fleet sailed in 1598, and from where, perhaps, it took back to Holland one of the oldest Muslim texts in Javanese. Schrieke published it in 1916 as the Book of Bonang, thereby associating

28. W. L. O1thof (ed. and trans.), Babad Tanah Djawi in Proza ( 2 vols.; The Hague: M. Nijhoff, 1941). 
it with the most famous of the Saints of Java, to whom it is ascribed by the copyist.

Drewes re-edited and republished the text in 1969 as The Admonitions of Seh Bari. 29 He argues convincingly that it has nothing to do with the Bonang of either legend or history, but that an attribution to Bonang was added to the manuscript to make it appear more impressive. In itself, it is not an important text. Since it is simply the notes taken by a pupil (unknown) of his teacher's (Seh Bari--of whom only the name is known) lectures, it is something like one end of a telephone conversation. Yet it is the evidence we have been looking for of an Islamic educational institution, perhaps in the heart of the port city of Banten. ${ }^{0}$ Drewes suggests that it may have been written about 1590.31

At present it is not possible to follow any further the development of this tradition in Banten. But it is possible, from 1550 onwards, to see remarkable developments in the Islamic history of Aceh. Schrieke notes that the powerful Acehnese sultan, ${ }^{C} A l a \bar{a}$ al-Din Ri'āyat Shäh al-Qahhār (1537-68), dispatched ambassadors to the sultan of Turkey requesting help against the Portuguese. He adds that the sultan sent him some craftsmen skilled in casting cannon, and reports Pinto as saying that he did have Turkish auxiliary troops at his disposal in 1539.32 Schrieke also refers to other European accounts mentioning ambassadors sent (from Aceh) to Turkey in 1564, and of artillery men and guns being sent (to Aceh) from Egypt. Egypt, it will be recalled, had been part of the ottoman empire since 1517. The Turks, moreover, had a fleet, from Egypt, operating in the Indian Ocean as early as 1538 , and asserted their presence in the Indian seas in the 1570s.33

This extension of Ottoman power went pari passu with the growth of Acehnese political and military power to the extent that in 1602 François Pyrard remarks: "Al1 the people in the Indies, or on the other side of the Cape of Good Hope, when they would go to Sumatra, merely say that they are going to Achen: for this city and port has acquired the name and reputation of the island."34 Moreover from 1570 onwards we have a record of a series of scholars from the Indian subcontinent and Western Asia: Schrieke presents the most convenient summary of information, noting that a scholar from Mecca named Muhammad Azhari arrived during the reign of the Sultan of Aceh 'Ali Ri'ayat Shah $(1568-75)$ and remained there until he died in 1630. In 1582, during the reign of Sultan 'Alā a1-Din (1577-86) two scholars arrived from Mecca, Muhammad Yamanì and Shaykh Abū ' 1 -Khayr b. Shaykh b. Hajar, author of al-Sayf al-Qātic (the Cutting Sword) dealing with the Fixed Prototypes ( $a^{c} y \bar{a} n$ thābita) a concept having a special place in the monistic theosophy of ibn 'Arabi. They are followed by a Shaficite scholar from the Gujerat, Shaikh Muhammad Jaylanī G. Hasan b. Hamid,

29. G. W. J. Drewes, The Admonitions of Seh Bari (The Hague: M. Nijhoff, 1969).

30. Drewes remarks that since Javanese tradition has preserved the memory of a Seh Bari of Karang, it is possible that the text had its origin at the renowned school of religion in Karang. Drewes, Admonitions, p. 13. In view of the text's (spurious) attribution to the East Javanese Saint Bonang, he does not accept the view of the first scholar to describe it, Taco Roorda, that it originated from Banten. (Ibid., p. 2.) Wa'llähu $a^{c} 1$ am bi 'l-sawāb!

31. Ibid., p. 9.

32. Schrieke, Studies, p. 245.

33. Ibid., p. 246.

34. Ibid., p. 245. 
a Kuraishite born in Ranir, an uncle of che later and better known a1-Raniri. ${ }^{35}$

There is no need to stress that there is a qualitative difference between the style and structure of Islamic civilization as it became rooted, fecundated and developed in Aceh, and the kind of information supplied by the Sejarah Melayu. The closest Acehnese equivalent to the Sejarah Melayu is a long but incomplete work which Teuku lskandar has published as the Hikayat Acheh. ${ }^{36}$ Iskandar suggests that it is devoted to the praise of Iskandar Muda (1607-30), the greatest ruler of Aceh. It does not include any specifically Islamic episodes, but occasionally an indirect reference indicates a knowledge of Islam far more profound than anything occurring in the sejarah Mezayu. Consider for example "the following citation from the early "mythological" section of the work:

Hai, tuan puteri, mengapa tuan malu melihat hamba? Telah dilahirkan Allah saat hari nin pertemuan tuan puteri dengan hamba hendak menyatakan pertemuan kita yang batin itu.

( 0 princess, why are you embarrassed to see me? God has made manifest this day our meeting in order to reveal our hidden meeting within him.) $)^{37}$

The reference is to the ibn 'Arabi tradition of monism which sees all the prototypes of created things from one aspect as pre-existing in the divine mind and identical with each other, and from another aspect as individuated at the level of creation, and able to meet and see each other in this dirferentiation. Although embedded in a traditional framework, the use of this metaphor has something of the character of a metaphysical conceit that we find in the poetry of John Donne. It shows that the author understood clearly at least the basic principles of ibn 'Arabi's system, and his use of it in this way is all the more striking because it is not self-conscious.

Throughout this period, that is, the second half of the sixteenth century, in addition to its contacts with Turkey and Egypt, Aceh was developing its relations with the Mogul Empire. In fact it is established that the rulers of Aceh took the structure of the Mogul court as the model for the administrative center of their own kingdom. 38 Iskandar has drawn attention to the possibility that the Hikayat Acheh referred to earlier had as a prototype the Persian Akbarnama, the work in honor of Akbar (Moghul Emperor 1556-1605) compiled by Abu'1-Fazl between 1596 and 1602.39 Iskandar's comparison of the two works is by no means detailed, but this apart, a sizeable corpus of Muslim learning and 1 iterature, rendered into Malay from Arabic or Persian, found its way to Aceh during these fifty years, which grew very considerably during the seventeenth century. One need only mention the book sayf $a z-Q \bar{a} t i^{c}$ brought to Aceh in 1582 referred to above, to the rendering in Malay in 1603 of the Persian Taj al-Salatin (The Crown of Kings), to the fragment of the Hikayat Muhammad Hanafiyyah, obtained by Pieter

35. Ibid., p. 243.

36. Teuku Iskandar, "De Hikajat Atjêh," Verhandelingen van het Koninklijk Instituut voor Taal-, Land- en Volkenkunde (VKI), XXVI (1958).

37. Ibid., p. 67.

38. Schrieke, Studies, p. 252.

39. Iskandar, "De Hikajat Atjêh," p. 20. 
Floris in Aceh in 1603 or 1604,40 the Arabic text of al-Busiri's Burdall (the poem on the Prophet's cloak) or the remark in the introduction to an Arabic Ms. in the Jakarta library, that the very popular mystical work al-Tuhfa al-mursala $i l \bar{a}$ rüh $a l$-nab $\vec{\imath}^{4} 2$ (The Gift Addressed to the Spirit of the Prophet) compiled in 1590 by the Indian author Muhammad b. Faḍl Allah a1-Burhanpuri was sent from India to Aceh.

This intellectual activity laid the foundation for, and stimulated the production of original works by local authors, among whom primacy of place and honor must be given to Hamzah Pansuri (d. 1600). His writings, in prose and verse, are the first manifestation of an independent Islamic intellectual life in the Malay world. At a time and a place when numbers of Persian and Arabic works were being rendered into Malay, it is not surprising that he too should have set out to write mystical sya'ir (quatrains), and commentaries upon them in Malay (for the benefit of those not knowing Arabic or Persian) setting out the principles of the school of mysticism that he followed. He was the first writer to have used Malay with fluency, vigor and passion to express mystical ideas and emotions.43 Yet he remains a shadowy figure. Since many of his works were destroyed, it is not possible to be sure whether he was a gifted religious writer who managed to weave into a theosophical system the more popular aphorism and ideas of the ibn 'Arabi school, or whether he was a thinker with a scholarly knowledge of Arabic and Persian. His Arabic citations (those in Persian are few) are mostly part of the common tradition of Sufi wisdom, passed on by the oral tradition, and it was these that he was able to orchestrate effectively into Malay. At all events it is not possible to associate him with other Malay or Arabic teachers, or to see him as representing a point in a complex educational network. For a11 intents and purposes, he was a loner who appeared, and vanished suddenly, with whatever school he founded dispersed by a subsequent change of fashion, and many of his writings lost in the accompanying persecution and book burning.

A change in the character of mystical writing becomes apparent in 1601 when Shams A1-Din began his career as a religious writer at the Acehnese court. This, it should be stressed, is only to be expected. Islam is not monolithic in character, and just as there is a variety of styles and schools of Islamic thought in different parts of the archipelago (the ideas of Hamzah for example, could never be confused with those of Seh Bari) so one may detect in changes of emphasis within the history of a single state. The intellectual framework of Hamzah's mysticism is very close to that of al-Jili. Shams al-Din, on the other hand, had obviously accepted as his own the framework of seven grades of being first set out in the short work of Muhanmad b. Faḍl Allah that was sent from India to Aceh, the Tuhfa.

40. See Winstedt, "History," pp, 114 and 88.

41. G. W. J. Drewes (ed. and trans.), "Een $16^{\text {de }}$ Eeuwse Maleise Vertaling van de Burda van al-Būsīrī," VKI, XVIII (1955).

42. Ms. KBG 97 Arab (Jakarta) $f .4 v-93 v$, fol. 5. The commentary is called: alMawāhib al-mustarsala 'alā '1-tuhfa al-mursala. An edition and rendering in English of the Tuhfa itself is in A. H. Johns, The Gift addressed to the Spirit of the Prophet (Canberra: Australian National University Oriental Monograph Series No. 1, 1965).

43. The most substantial study of the man and his work is to be found in The Mysticism of Hamzah Fansūri by Syed Muhammad Naguib al-Altas (Kuala Lumpur: University of Malaya Press, 1970). 
Another change of style, this time not a natural development, but imposed by force, occurred in 1637. Iskandar Muda died in 1636, and his successor, Iskandar II gave his ear to al-Raniri, the nephew of Muhammad Jailäni, referred to earlier. We know little enough of the spiritual affiliation of Shams al-Din. We are scarcely better informed concerning that of al-Raniri, despite his prolific writings, and the detailed investigation of his background by Drewes. 44 For all that we know of their works, we are not able to discover for them the kind of background and support that Muslim learning requires, and which perhaps would better enable us to understand their writings and attitudes: from whom did they study, what religious education gave them their formation? Al-Raniri was probably one of a type of peripatetic ulama' who sought fortune, patronage and influence at a royal court; at the same time he probably represented a particular school--the views that he wished to impose were therefore, not simply his, as an individual, but those of the school and tradition in which he had been trained--of which unfortunately we know very little.

To this extent them, we are disappointed. The two great themes in Islamic learning are transmission and authority: on whose authority is this judgement or opinion put forward? If it is not given on the personal authority of the individual uttering it, what is the 1 ine of transmission through which it has been communicated to the individual uttering it?

It is not until the time of Abd al-Ra'uf that this line of transmission of teaching and authority is established. For in him we are able to see a Malay author in relation to his own teachers in Medina-to see him as a point on a network of religious teachers associated with diverse schools in various centers of learning, each with his own line of transmission guaranteeing the standard of his learning and the legitimacy of the doctrine that he taught. He does not begin to make his mark on the Acehnese scene until after 1661 when he returned to Aceh after spending twenty years or so in Arabia. He died in Aceh in 1693--which if he were born in 1615, gives him a very advanced age.

He supplies information concerning his stay in Arabia in a colophon to one of his works, written, as was the custom of the time, to prove his bona fides as a teacher. In it he 1 ists the places in Arabia where he studied, and the people from whom he studied. We read, for example, that he studied at half a dozen places in the Yemen, scattered along the pilgrimage route from Aden to Mecca, including Zabid, Mukha, Tayy, Bayt Faqih and Mawzac. (A study of the distribution of these place names on a map is instructive. It also indicates that, in the seventeenth century, the Yemen was dotted with religious schools.) Then he traversed Arabia, and studied at Doha on the Qatar Peninsula. He also studied at Jiddah, the port of Mecca, Mecca itself, and Medina. 45

In the traditional manner, he divides his studies into those of the "exterior" and "interior" sciences. Exterior are those which concern Jurisprudence, the Law, Exegesis and Tradition and so forth. These he studied at various centers in the Yemen as he indicates.

44. G. W. J. Drewes, "De herkomst van Nuruddin ar-Raniri," BKI, III, No. 2 (1955), pp. 371-51.

45. This information and that given in the following paragraph is supplied at the end of his work 'Umdat al-mubtajin (Leiden Ms. Cod. or 1933), pp. 141-54. 
Certain of his teachers there receive a special mention. In Zabid, for example, he notes that he studied the art of Qur'anic recitation with Shaykh Abdullah al-'Adani, "the best of the reciters of the Yemen." He notes that the longest period of time that he spent studying these "external" subjects was with a Shaikh Ibrahim b. "Abdullah Jamcan at Bayt al-Faqih, who introduced him to the "Pole" of his era, Ahmad Qušaši at Medina, from whom he studied the interior sciences-that is, mysticism. Abd al-Ra'uf does not grace this colophon with any dates. But he remained a close associate with Qušaši until the latter died in 1661. He then studied with Qušaši's successor as head of the order, Burhan al-Din, Mulla Ibrahim, the greatest scholar of his age in the tradition of Ibn 'Arabi, who subsequently gave him the authority on his return to Aceh to found the Shațāriyya.

The general picture of Abd al-Ra'ūf's career, and others like him, is conventional enough: the subjects studied, the moving from teacher to teacher, the demonstration of the talent that was to produce a rendering of the entire Qur'an in Malay, the entry into the mystical order, winning the respect of one of the greatest Sufi minds of the century who appointed him to propagate the order in his own country, and who continued to correspond with him, giving advice and answering questions across the "Arabic-speaking Mediterranean" of the Indian Ocean.

Various of his works are extent, written during the twenty-five years after his return to Aceh, while he won an extraordinary reputation for learning and sanctity. Voorhoeve 1 ists twelve of them. 6 They were compiled for students with various levels of ability, and include a scholastic exercise interpreting two lines of mystical verse attributed to ibn 'Arabi, the rendering into Malay of an answer sent to him by his teacher, Mulla Ibrahim, on a question relating to popular local beliefs on the approach of death, long treatises on the recitation of the dhikr, and his most ambitious work, a rendering in Malay 4 of the Commentary on the Qur'an by al-Bayḍāwì, Anwāru ' $\imath-\operatorname{tanz} \vec{\imath} \imath$ wa asräru ' $l$-ta'wiz (The Lights of Revelation and the Secrets of Interpretation). The bent of his mind was practical, and he had the concern of a religious teacher for his pupils. Thus his work was always based on a concern for them: to enable them to understand Islam better, to warm them of dangers, to help their devotions, to preserve them from error, and to warn them against intolerance.

All of his writings in Malay were oriented to Malay conditions, and set at a level appropriate to his students. This explains the pedestrian character of much of his writing and the choice of the topics that he discussed. Thus the corpus of his works that survives in Malay is not particularly striking in so far as its originality and intellectual depth is concerned. Given the pedagogical intent of his writings this is not surprising.

His rendering of al-Bayd̄âwi's work has been printed several times, and is still readily availabie. At the end of the work, a triumvirate of certificators of Jawi books at Mecca declares that the translation has been compared with the original, and a certificate issued that

\footnotetext{
46. P. Voorhoeve, "Bayān Tadjallī," Tijdschrift voor Indisch Taal-, Land- and Volkenkunde (TKI), LXXXV, No. 1 (1952), pp. 108-16.

47. With the title Tarjumān al-mustafid (Constantinopole 1302/1884 and currently reprinted by Sulayman Marcí, Singapore).
} 
nothing has been added, omitted or changed. While no detailed study of this major work has been made (although Snouck Hurgronje has drawn attention to some errors in Abd al-Ra'ūf's translation ${ }^{48}$ ) even a cursory glance indicates that very much has been omitted: grammatical analyses, variant readings and illustrative anecdotes; indeed in some places 'Abd al-Ra'ūf's explanation of the meaning of a verse has no relation to al-Baydāwì's interpretation at a11. Thus we are left with little more than a paraphrase of the Qur'an in Malay. Clearly, the committee of censors in giving the work their imprimatur had the mental reservation "for local conditions."

This brings us to a crucial issue: what was the standard of Abd al-Ra'üf's scholarship? To what extent were his Malay writings and translations prepared by himself directly, to what extent by senior pupils working under his supervision and allowed the authority to use his name? And this raises the further question: is there a genuine Muslim intellectual life at all in the Malay world? Were those who wrote in Malay, simply, as Drewes puts it, unoriginal purveyors of second-hand doctrines, or were the authors of Malay language texts concerned solely with pastoral needs, who, when they studied and explored in more depth the traditions of Islam, did so in Arabic? In fact one cannot get a full picture of the intellectual achievements of Jawi Muslims from writings in the regional vernaculars.

An analogy may be drawn between the role of Arabic in the seventeenth century and that of Dutch in later times. Were one to judge the intellectual range of the peoples of the Indies during, say, the first thirty years of the twentieth century by the Malay/Indonesian language texts published by Balai Pustaka, the achievement would not appear very impressive. Such a judgement would not reflect the fact that there were Indonesians to whom Dutch was a language through which they had access to the whole tradition of Western thought and 1iterature. The publications of the pre-war Balai Pustaka were not directed to such as these, but to groups to whom literacy was something new, to the lower and lesser educated classes. In the seventeenth century, the Islamic tradition represented the world of intellectual life and culture outside of Java; and Arabic was as well-known by those who participated in this world as Dutch was among their equivalents two centuries later.

Therefore to answer this question we must return again to the career of Abd al-Ra'ūf in Medina; assuredly he was not the first Jawi, nor the only one to study there, and a succession of others followed him, where his vigorous travels in the Arabian Peninsula, the range of subjects he studied, the esteem that he won from his teachers, and the continued contacts with Medina after his return, do not suggest an incompetent scholar.

This in fact will highlight the importance of 'Abd al-Ra'ūf, for even if it does not enable us to penetrate the self-effacing dedication of this most modest of men, for the first time it brings us face to face with some of the teachers of the Jawi in Medina, and equally, if not more important, it leads us to discover the presence of the Jawi in Middle Eastern writings. The two teachers that Abd al-Ra'ūf holds in the highest respect in his academic biography are Ahmad Qushashi, (1583-1660) and Qushashi's pupil and successor as head of the Shattariyya order, Burhan al-Din Mulla Ibrahim b. Hasan al-Kurani. In his

48. C. Snouck Hurgronje, The Achehnese (Leiden: E. J. Bril1, 1906), II, p. 17 n. 6. 
Malay writings he refers to them both. Qushashi was a major scholar who has written important commentaries on various of the works of a1Jili. Most of his works, however, are not widely known. Brockelmann attributes only twelve works to him. 49 Ibrahim on the other hand, has at least a hundred works attributed to him (see below), only one of which, a minor treatise, has been published, and is clearly a major figure. As far as Abd al-Ra'uf is concerned, intellectually Ibrahim appears to have been the more important.

Ibrahim, the silk al-Durar tells us, was a resident of Medina. A man of great learning, he was a profound mystic, a Naqshabandi, and the author of many books. He was born in 1025/1616 (in Kuran near Nishapur) and studied first on his own account. He travelled to Medina and studied there from the best scholars of his age, and likewise in Damascus and Cairo. When he settled in Medina his status rose, and students flocked to him from distant lands to study with and learn from him. He taught (in a corner) of the Prophet's mosque, and wrote over a hundred useful books. He was a mountain among mountains of learning, a sea among seas of perception. He died on a Wednesday after the casar prayer on the 28 of Rabic a1-Thani, $1,101 / 11$ January 1690 at his home outside Medina, and was buried at Balqic (the principal cemetery of Medina). May God have mercy on him. He wrote on various subjects, often in answer to questions. And prominent among his pupils and concerns were the Jawi from the Indies--including Abd al-Ra'ū and his associates and successors. 50

Ibrahim was a teacher with a particular kind of intellectual and personality formation. As a mystic and a thinker he espoused not only a particular form of devotion, and inwardness of spiritual understanding, but an intellectual understanding of God and His role as Creator, and the relation of the Creator to Creation. His view was not that of al-Ashcari, who in his concern to maintain the omnipotence of God and His continually exercised creative power, and to rebut the Hellenizing tendencies of "the philosophers," saw the world as a series of atoms individually re-created. Ibrahim and the school of Ibn 'Arabi took a more dynamic view, and saw in the concept of the Unity of Being (Wahdat $a l-W u j \bar{u} d)$ and a mystical interpretation of the Qur'an a means of better understanding the nature of God, and of leading a spiritually deeper life.

It is hardly necessary to stress how important it is to have at first hand, from Abd al-Ra'ü's teacher, the doctrines and ideas that Abd al-Ra'ū's own pupils in Aceh were to disseminate throughout the archipelago. But there is a further dimension to Ibrahim's importance. One of his pupils, al-Hamawi, compiled a biographical dictionary of the religious teachers of the eleventh century A.H. In it, of course, his own teacher Ibrahim had a place; and this biographical dictionary

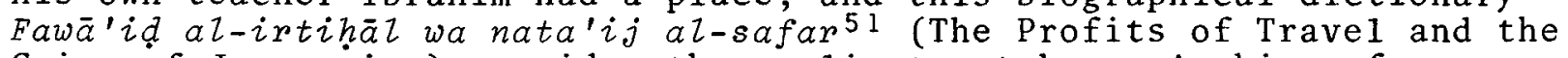
Gains of Journeying) provides the earliest yet known Arabic reference to Jawi students in Medina.

49. Car1 Brockelmann, Geschichte der Arabischen Litteratur (Leiden: E. J. Bri11, 1943-49), II, pp. $514-15$.

50. a1-Murādī: Kitāb silk al-durar fī a $a^{c}$ ān al-qurn al-thānī cashar s.v. Ibrāhīm al-Kūrānī.

51. Ms. Dār a1-Kutub Cairo Tārīkh 1093. 
a1-Hamawi reports that he first met Ibrahim in $1086 / 1675$ during a visit to Medina and read with him part of his commentary on the Tuhfa. In the course of this visit Ibrahim spoke to him of the Jawi students (that is, those from the Malay lands), and what they told him about themselves. They mentioned to him that in their homeland they used for religious instruction al-Tuhfa al-mursala ila ruh al-nabi (The Gift addressed to the S. of the P.), a text by the Indian author Muhammad $b$. Faḍl Allah (d. 1619) which, as already noted was written in 1590, and according to an anonymous commentary in the Jakarta Museum a1ready mentioned, was sent to Aceh from India. al-Hamawi puts it this way:

Our Shaikh Ibrahim al-Kūrāni told me that one of our Jawi companions--and he was reading the Tuhf $a$ with him at that time, and we were present--informed him that this treatise and matters it treats was popular and famous in the lands of the Jawi, and that it is read in their religious schools, and that youths study it as a minor treatise on the rudiments of their studies. And every reasonable minded man knows that this could only have happened by virtue of its dedication to the Prophet, and the author's (pious) intention, otherwise the best of the Sufi doctors would have rejected it, nay more, their followers; nay more the general public, nay more, even youths at the schools. But when God desires good for one of his servants, he makes faith loved to him, and makes both it and those things conducive to it attractive to his heart.

So just as the child learns the basic doctrines and obligations of religion by imitation without understanding them fully, but when he becomes adult and his mind has developed he perceives their true significance, in precisely the same way if a person is instructed in the great truths of religion (that is, mysticism) when he is a child, when he is adult God gives him the light to understand them fully, and this he finds easy because he is already familiar with the formulations of them that he has learnt by heart. . . . And what I believe to be the case in their (the Jawi's) homeland is that the young student is first taught those articles of faith that are obligatory for all creatures, that is, the outward sense of the Qur'an and prophetic practice and the teachings of the righteous ancestors, and instructed to read elementary texts on these topics by the major authors of the Sunni tradition. After this, if his teacher wishes that he should read books suitable to those adult in faith and gain blessings from their words, he warns him that what he is teaching him now will not be understood at once, but that there are men devoted to it . . . who are the dedicated servants of it and heirs of the prophets. Their hearts are filled with the knowledge and love of it, and have no place for anything beside it.

The value of this method of instruction is that the mind does not become set in what has become familiar and accepted from childhood, or believe that there is nothing beyond it, no level of understanding higher than it, or savor sweeter than it such as God may give to those pure of His loved ones that He wishes over and above what is taught to the common herd, which is not inconsistent with what is in the Book and Tradition, and neither does it deviate from what the common herd are ordered to believe. ${ }^{52}$

It is information of this kind that "completes the circle," for we now have a picture of the line of transmission from the Jawi teacher to an Arab Shaikh (in fact Ibrahim was a Turk) in Medina, and the Arab

52. Ms. Tārīkh 1093 s.v. Mullā Ibrāhīm al-Kürānī (Abridged and paraphrased) . 
both teaching the Jawi students, and noting what they told him of themselves. It is the only Arabic text yet known that gives an account of what can only be called a philosophy of education used in the Malay world. Although the text is not specific as to the place where this highly civilized form of religious instruction was practiced (Jawi is a general term), Aceh itself is certainly not excluded. Not that it should be imagined that it was the only philosophy of education in vogue. It must be stressed again and again that the centers of Islamic education in the Malay world were discrete, and that each center must be studied as a unit, and that only after iines of transmission and links had been detected, is any kind of generalization possible.

As for Ibrahim's reading of the Tuhfa (The Gift Addressed to the Spirit of the Prophet) with the Jawi, it was to yield his most important single work Itha $f$ al-Dhaki bi sharh al-tuhfa al-mursala ila' $l$-nabi (A Presentation to the Discriminating in Explanation of the Gift Addressed to the Spirit of the Prophet). The Tuhfa itself is not a major work. Yet it became immensely popular, perhaps, because like al-Qushashi's manzüma fi Tawhíd (rhymed credal statement), as an abridgement of various aspects of Muslim theosophy, it served as a convenient starting point for commentaries in which could be set out at length a general exposition of the principles of Süfi thought.

Ibrahim's commentary is an outstanding piece of scholarship and eloquent pleading both for the recognition of kashf (divine enlightenment) as a means of understanding the inner meaning of the Qur'an and Tradition, and for acceptance of the Unity of Being as the philosophical system most appropriate to the religious and moral truths, the symbolism and cosmology presented in the Qur'an. It is the summation of five hundred years of the ibn 'Arabi tradition, presented as a viable "other way" superior both by theological and philosophical criteria, to al-Ashcārí's occasionalism. And it was written for the Jawi perhaps because Ibrāhim had been told of the intolerant and oppressive role of al-Rānîrî in organizing persecutions and book burning thus causing bewilderment and concern in religious circles in Aceh. Ibrāhim, after a majestic and magisterial exordium begins the
work proper:

We have had reliable information from a company of Jawi, that there have spread among the inhabitants of the lands of "Java" some books on Realities, and esoteric teachings by men attributed with knowledge because of their study and the teaching of others, but who lack any understanding of the Law of (Muhammad) the Chosen, the Elect (of God), and even less of an awareness of the knowledge of Realities bestowed upon those who follow God's path, may He be exalted; those brought close to Him, those excellent ones, or those who have entered upon anyone of their paths based on the Book and the Sunna through perfect obedience, outwardly and inwardly (physically and spiritual$1 y$ ), as have the devout and pure. This has led many of them to deviate from the right path, and given rise to faulty belief, in fact they have been attracted to camp in the valleys of unbelief and heresy--we take refuge in God from error and from all evil, in secret as in public.

Further, these Jawi have told me that among the best known of books among them was the compendium entitled al-Tuhfa al-mursala ila ' 2 -nabi (The Gift Addressed to the Prophet) written by the gnostic of God, may He be exalted, Shaikh Muhammad ibn Shaikh Fadl Allah alHindi al-Burhanpuri, may Almighty God render him of service. And 
more than one of them has asked my humble self to prepare a commentary upon it to make clear the conformity of the questions (it discusses) to the basis of the principles of religion, confirmed by the Noble Book, and the Sunna of the Lord of the Apostles, may God's blessings and peace be upon him and upon them and their families all of them, a reply came--hoping that, by leave of God, Lord of the worlds, it will yield a sound fruit, despite the fact that my ability to express myself is slight, and knowing that the communication of what has been beheld to the understanding in intelligible language in harmony with the Book and Sunna is a high mountain difficult to climb. But God is All-powerful and Mighty, He has "Let forth the two seas that meet together, between them a barrier they do not overpass" (Qur. 55: 19-20), He it is who is able to raise whomever of His servants He wishes to the meeting point. So what is necessary is to do one's best; it is God from whom help is to be sought, Who is to be asked in words of humility and neediness to give me the grace to give a sufficient explanation, selected from the writings of those successful in unveiling and vision, those who have beheld the Real (through His names) after observing them, by way of perfect obedience, the people of Truth and Devotion, "Oh Lord, enlarge my breast and make my task lighter, and loosen the knot on my tongue that they may understand my words." "My Lord, give me judgement, and join me with the righteous; and give a tongue of truthful concerning the later generations. . . . Amen." 53

From the text it is not possible to judge how many years were involved, nor precisely how many of the Jawi spoke to him, nor who they were. What is clear is that it was a task he took seriously, that he prayed seriously and long at the tomb of the Prophet in Medina about the work, that he made a prayer for guidance, and did not begin his work until he had received an answer to this prayer, indicating that it was right for him to undertake this task.

The work consists of several sections and addenda dealing with various topics. One outlines the principles underlying the interpretation of the Qur'an and Tradition in the mystical sense. This implies that it was these principles that Abd al-Ra'ū mastered, and that he passed on to his disciples. Such a detailed presentation of these principles has not yet been discovered in Malay, but it is clear that they were known. Another concerns the duty of obedience to the Law. No degree of religious enlightenment can ever dispense the Muslim from this obligation. Another concerns the contrasting yet complementary requirements of Law and Wisdom. The issue behind this discussion is an important one in a monistic system, which when it comes to terms with religious dogma, and the doctrine of eternity in hell for unbelievers, has to see, even in hell, and the position of the damned in he11, an illustration of the divine perfection. Ibrahim's explanation is that the blessed are in heaven by Law and by Wisdom, those in Hell are there by wisdom only. The argumentation is complex, and indeed was discussed by a1-Jili, who remarked that eventual1y the damned would take pleasure in their torment, just as a man with an itch gained pleasure from scratching which relieved it. The relevance of this discussion to the answer of "Pasai" is obvious. The commentary concludes with a long section devoted to the theoretical justification of the principle of the Unity of Being in which ibn Sina "Prince of the Intel-

53. This and other citations from the work are taken from a critical edition and translation being prepared by the present author and Dr. Nagah Mahmoud a1Ghoneimy of al-Azhar University, Cairo. 
lectuals" is called as a key witness, and the doctrine of the Unity of Being is proposed as the only cosmology that can offer a solution to the problems that vexed the minds of the scholastic theologians.

The heart of the text however is the dialogue between Ali and his servant Kumayl, which Ibrahim translated from the Persian, and on which he wrote a commentary. The sheer religious power of this dialogue, which has the terseness and paradoxical character of $Z$ en, is difficult to convey in English. Despite the rather technical, and at times mechanically scholastic character of sections of the work, the repetition of a word or key phrase at different points is sufficient to awake echoes of this scene which is the final justification of the argument and explanation of the relation between outer practice and inner understanding: the experience of the presence of God, and a vision of His glory behind all phenomenal being.

And sufficient to achieve this grade (of enlightenment) are the famous five words of 'Ali, the commander of the Faithful in answer to Kumayl b. Zayyād, his closest friend and receiver of his generosity and kindness.. . They are that Kumayl asks Alĩ : What is Reality?

Ali: What business have you with Reality?

Kumayl: Am I not your closest friend?

Ali: Yes, but what overflows from he is shed upon you.

Kumayl: Would one such as you fail a questioner?

Ali: The revelation of the praises of the Majesty without any limitation.

Kumayl: Teach me more.

Ali: The obliteration of what is illusory through the radiance of knowledge

Kumayl: Teach me more.

Alis The destruction of the veil through the mastery of the Secret.

Kumayl: Teach me more.

Ali: The ecstacy of oneness through the unification of Tawhīd.

Kumayl: Teach me more.

Alí A light is rising from the dawn of eternity, and its traces illumine the edifices of Tawhīd.

Kumay 1: Teach me more.

Ali: Put out the lamp, for the sun has risen.

This rendering is not worthy of the original, which in any case needs extensive commentary. But the significance of this passage and the work as a whole lies in the information it gives us of the kind of material studied by Jawi students in Medina over and above the standard and rather dull handbooks on fiqh, uşuz kalām and the like. It reveals a strength and character of personality making an impress on other personalities. And it is not difficult to see in the gentleness and tolerance of Abd al-Ra'uf a mirror image of the kindness of his teacher, Ibrāhìm.

'Abd a1-Ra'üf, for example never referred directly to the witchhunts organized by al-Raniri. In cases of disagreement with any doctrine he expounded, he contented himself by quoting the tradition: "Let no Muslim call another Muslim an unbeliever. If he does so, and it is true, what is there to be gained by it? And if it is not true, the accusation is turned back upon himself." In his works he makes no reference at all to al-Raniri or his writings, yet they must have been known to him. It is in the same spirit that Ibrahim again and again 
throughout his work urges the golden mean: avoiding erring either by excess or insufficiency, and remarking as a leitmotif: it is better to reconcile opposing viewpoints than to choose either one of them or the other.

Ibrahim wrote for the Jawi. His work is a masterpiece, establishing him as one of the finest minds of his century in this area of the Islamic disciplines. It is also clear that he expounded it to Jawi students in Medina. Did it ever reach Sumatra? Abd al-Ra'ũf refers to various of Ibrahim's books in certain of his writings, including works of Ibrahim which Ibrahim himself refers to in his own work, which must, therefore, have been subsequent to them. He does not refer to the Ithāf by name. In any case it was a late work. Yet the Itḩa $f$ is essentially a reorganization of material on various topics that Ibrahim had written about elsewhere. And given the importance of oral instruction, one does not necessarily need the book to have the ideas that it expresses.

Even so it is disappointing that no text of the Ithāf has been discovered in Southeast Asia. Three manuscripts are extant in Cairo. I am informed by Dr. Osman Yahya that there is a copy in Istanbul. This apart, the furthest east that a copy has been found is one from the library of Tipu Sultan (1783-1799), Mysore, which is rather poor.54 Yet known or not, it is clear that the work contains in manageable compass a large body of material which is relevant to and provides a reference point for some of the scattered ideas written in the various regional languages of the island archipelago region.

It is not possible at this stage to do more than suggest the possibilities of this approach to the study of Islam in Southeast Asia, whether for the modern or the older period. A by-product of this focus on the intellectual 1 ife of Aceh, and the dramatic quickening in the development of Muslim learning there after 1570 suggests that the position of Malacca as a seat of Muslim learning may have been exaggerated. In fact not only are the Islamic episodes in the Sejarah Melayu rather light weight in character, but they may have been interpolated into an earlier draft of the work which was not much more than a list of kings (Sulalatu $l$-Salatin) when the 1612 version of the work, represented by Raffles 18, was gazetted in Johore. It would be very much in the Johore-based dynasty's interest, in view of their rivalry with Aceh, to claim for their own ancestors an Islamic reputation as distinguished as that enjoyed by Aceh. Each of the Islamic episodes in the Sejarah Melayu earlier in this paper have a counterpart so evidently manifest in the history of Aceh, that it is difficult to avoid the suspicion that they derived from Aceh.

For the modern period, it should be emphasized that even for the study of Islam in modern Indonesia, the expression "Indonesian Islam" has a limited meaning. It is, for example, properly used in Boland's book The Struggle of Is lam in Modern Indonesia. 55 The "struggle" that Boland describes is a political one at the national leve1; it is not spiritual, moral or intellectual; it does not concern prosyletization or the formulation of legal judgements. It is a struggle on the part

54. D. Loth, A Catalogue of the Arabic MSS in the Library of the India Office, London 1877, No. 684 .

55. B. J. Boland, The Struggle of Islam in Modern Indonesia (The Hague: M. Nijhoff, 1971). 
of Muslim groups acting politically to manipulate the constitution of the state to incorporate the legal requirement for Muslim communities of the state to live according to Muslim Law. In fact it is concerned more with an aspect of the political history of Indonesia than with Islam as a socio-religious force, or a theological reality. It is Islam with a "political face."

An analogous example of this approach is Castles' book on the cigarette industry in Kudus. ${ }^{56}$ Again, the focus of the investigation is sharply defined: it is a study of Muslims acting economically in a particular way. This particular way of acting is not so much to correlate Islamic thought and devotion as to Islamic allegiance. It is about the economic behavior of people at a certain time and place, who happen to be Muslim--Islam with an "economic face."

Both books are conceptually viable because they do not confuse their categories of analysis. Yet valuable and important as they are, they do not take the place of the study of Islam as a discipline in the field of religious studies. And the fact that they use the word "Islam" in non-religious contexts and in relation to other disciplines, should not obscure the fact that these concern only certain phenomenological aspects of the behavior of Muslims. These cannot be fully understood outside of the study of Islam as an intellectual and spiritual tradition.

If we wish to understand the depth and extent of this intellectual and spiritual tradition, it must be realized that much of what passes for a knowledge of Islam in Southeast Asia is at best based on vernacular popularizations, the presentation by the Muslim elites of material either for popular consumption, for political solidarity-making purposes, or to impress the foreigner.

There is an Arabic tradition of Muslim learning in many of the regions of the Malay world that has sustained itself, sometimes against heavy odds, over two centuries. Jawi scholars have published significant works in Arabic in Cairo and Istanbu1. The Manuscripts section of the Jakarta Museum includes Arabic texts of many of the standard works of Islamic learning and some original works as wel1, gathered from various parts of the archipelago which have not yet received critical scrutiny. It is works such as these that the Muslim elite wrote for themselves and each other. It is from a study of such works in their regional settings that a clearer and perhaps more worthy understanding of Islam in Southeast Asia may be won.

56. Lance Castles, Religion, Politics and Economic Behaviour in Java: The Kudus Cigarette Industry (New Haven: Yale Cultural Report Series, 1967). 
